\title{
PHENOLIC SUBSTANCE CONTENTS AND BIOLOGICAL ACTIVITIES OF VERBASCUM INSULARE BOISS. \& HELDR. EXTRACTS
}

\author{
YUSUF ALAN $^{1 *}$, NIMET YILMAZ $^{2}$ \\ ${ }^{1}$ Faculty of Education, Department of Primary Education, Muş Alparslan University, 49250, Muş, Turkey \\ ${ }^{2}$ Institute of Science, Department of Biology, Muş Alparslan University, 49250, Muş, Turkey \\ *correspondingauthor:y.alan@alparslan.edu.tr
}

Manuscript received: March 2019

\begin{abstract}
In the present study, 17 different phenolic contents of Verbascum insulare Boiss. \& Heldr. ethanolic leaf (LEtOH), aqueous leaf pure (LPW), ethanolic root (REtOH) and aqueous root pure (RPW) extracts were determined by HPLC. Moreover, their antimicrobial, antioxidant and DNA protective activities were identified. Curcumin and salicylic acid were not detected in $V$. insulare LPW extract, whereas vanillin was not found in RPW extract. The gallic acid and 3,4-dihydroxybenzoic acid presence were not determined in any extract. Based on the results of the biological activity, it was found that the ethanolic extract showed a higher antioxidant and antifungal activity compared to pure aqueous extract and increased the DNA stability. As a result, it may be argued that the biological activity of the ethanolic extract is higher due to the total phenolics compared with the aqueous extract. Since no previous studies were available on the biological activities of this plant, the data obtained in the present study will contribute to future pharmacological studies.
\end{abstract}

\section{Rezumat}

În studiul prezentat, au fost studiate 4 extracte diferite ale speciei Verbascum insulare Boiss. \& Heldr. prin HPLC, pentru a determina conținutul total al fenolilor din extractul etanolic din frunze (LEtOH), extractul apos din frunze (LPW), extractul etanolic din rădăcini $(\mathrm{REtOH})$ și extractul apos din rădăcini (RPW). S-au determinat, de asemenea, activitățile antimicrobiană, antioxidantă și de protecție a structurii ADN-ului. Curcumina și acidul salicilic nu au fost evidențiate în extractul apos de frunze, iar vanilina nu a fost detectată în extractul apos din rădăcini. Acidul galic și acidul 3,4dihidroxibenzoic nu au fost puși în evidență în nici un extract. Ținând cont de rezultatele obținute privind activitatea biologică, s-a concluzionat că extractul etanolic prezintă o activitate antioxidantă şi antifungică mai puternică comparativ cu extractul apos, determinând și creșterea stabilității structurii ADN-ului. Se poate afirma, în concluzie, că activitatea biologică a extractului etanolic este superioară datorită cantității totale de fenoli, compativ cu extractul apos. Deoarece nu există studii anterioare privind activitățile biologice ale acestei plante, datele obținute în cadrul prezentei cercetări vor contribui la viitoarele studii farmacologice.

Keywords: $V$. insulare, antimicrobial, antioxidant, DNA, HPLC

\section{Introduction}

The use of plants as therapeutic agents is recognised from ancient times [3]. Many in vitro studies show that the obtained extracts possess antimicrobial activity $[28,38]$. In addition to their antimicrobial activities, the antioxidant features of the plants are also of importance $[1,19,34]$. Meanwhile, the food industry attempts to find plants that have natural resources alternative to chemicals as preservatives [7]. The Verbascum genus is a member of the family Scrophulariaceae and known as "mullein or king's candle" in the flora of Turkey. It has 233 species, 185 of which are endemic and more than 100 hybrids $[4,11,13,14]$. Verbascum species are used for their mucolytic, expectorant and diuretic actions in the traditional Turkish medicine. They are also used in the treatment of tuberculosis, bronchitis, dry cough, asthma, rheumatic pain, haemorrhoids, wound, diarrhoea and fungal infections $[12,17,25]$. The species of this genus include flavonoids, iridoide glucosides, neolignane glucosides, phenylethanoid glycosides, saponins, spermine alkaloids and metabolites like steroids [33, 35].

In the light of the given data, Verbascum insulare Boiss. \& Heldr. ethanolic and pure aqueous extracts, which were not examined before, were obtained, and 17 different phenolic contents were determined by High-performance Liquid Chromatography (HPLC). The antimicrobial effects of these extracts were determined with the hollow agar method, using three Gram-positive, four Gram-negative bacteria and three fungi. In addition, the in vitro antioxidant activities of these plant extracts were determined with four different methods and their effects on DNA were examined. 
FARMACIA, 2019, Vol. 67, 4

\section{Materials and Methods}

Collection and extraction of the plant samples

The $V$. insulare plant was collected during the vegetation period in 2018 from Güzeltepe Village located in Muş province (Turkey). The identification of these plant samples was made according to the Flora of Turkey by Murat Kurşat (Bitlis, Turkey). The plant sample that was made into herbarium material was encoded (Y. Alan: 4913) and kept at Muş Alparslan University, Central Research Laboratory Application and Research Centre, Muş, Turkey.

The plant samples were taken from the roots and leaves and were then dried in shadow. Fifty grams plant samples that were prepared for extraction were cleaned, ground and extracted using the Soxhlet extraction method in $300 \mathrm{~mL}$ ethanol and distilled water. Then, the ethanol and purified water were removed using an evaporator. The extracts were encoded as ethanolic leaf ( $\mathrm{LEtOH})$, aqueous leaf (LPW), ethanolic root (REtOH) and aqueous root (RPW), and were kept at $\pm 4{ }^{\circ} \mathrm{C}$ in dark-coloured glass bottles for the quantitative analysis and for the in vitro determinations in terms of phenolic substances and their biological activities.

Phenolic substance analysis

In order to determine the phenolic amount by HPLC, the last concentrations of ascorbic acid, gallic acid, 3,4dihydroxybenzoic acid, 4-hydroxybenzoic acid, transp-coumaric acid, myricetin, abscisic acid, quercetin, apigenin, kaempferol, curcumin, catechol, vanillin, caffeic acid, cinnamic acid, rosmarinic acid and salicylic acid standards were weighed in order to obtain solutions with a concentration of $10 \mathrm{mg} / \mathrm{mL}$. Then, $1 \%$ acetonitrile and acetic acid were added (at a rate of $1 / 9$, respectively) to the standards, and methanol was added in the same rates to prepare stock standards. The stock standards were used for the calibration curve after they were diluted as $10,25,50,75$ and $100 \mu \mathrm{g} / \mathrm{mL}$ [31]. The concentration of $V$. insulare extracts was diluted as $20 \mathrm{mg} / \mathrm{mL}$ by using the solutions that were used in the standard. The extracts were loaded to an HPLC by filtering with a $0.45 \mu \mathrm{m}$ membrane filter [1]. HPLC analysis was performed by using the Agilent Technologies 1260 Infinity II HPLC (Agilent, USA). The HPLC configuration consisted of a 1260 DAD WR detector $(272 \mathrm{~nm}, 280 \mathrm{~nm}$ and $310 \mathrm{~nm}$ wavelength), 1260 Quat Pump VL pump (1.0 mL/min flow rate), 1260 Vial sampler $(20 \mu \mathrm{L}$ injected $)$ and $\mathrm{G} 7130 \mathrm{~A}$ column furnace $\left(28^{\circ} \mathrm{C}\right)$. The analytical column used for the analysis was ACE 5 C18 (250 x $4.6 \mathrm{~mm}$ id).

Determining the antimicrobial activity

The antimicrobial activity of the $V$. insulare extracts was determined by using the hollow agar method [26]. In the present study, 7 bacteria (Bacillus subtilis ATCC 6633, Staphylococcus aureus ATCC 25923, Bacillus megaterium DSM 32, Enterobacter aerogenes
ATCC 13048, Escherichia coli ATCC 11229, Pseudomonas aeruginosa ATCC 9027 and Klebsiella pneumoniae ATCC 13883) and 3 yeasts (Yarrowia lipolytica ATCC 20460, Candida albicans ATCC 10231 and Saccharomyces cerevisiae ATCC 834), which were obtained from Muş Alparslan University Central Laboratory, were used; and 5 different antibiotic disks (erythromycin (E-15), ampicillin/sulbactam (SAM-20), rifampicin (RD-5), amikacin (AK-30) and fluconazole (FCA-25) were used for determining the antimicrobial activity of the extracts [1].

Antioxidant properties

Determining total antioxidant activity

Total antioxidant activity was determined in line with the thiocyanate method [21]. This method involved the oxidation of peroxide in a linoleic acid emulsion and spectrophotometrical measurements at $500 \mathrm{~nm}$. High absorbance indicated the excess amount of peroxide resulting from peroxidation. The stock solution was pipetted into the containers at desired amounts with automatic pipettes, and the volume was completed to $2.5 \mathrm{~mL}$ with the buffer solution. The absorbance of the samples at $500 \mathrm{~nm}$ was read against a blank. The incubation was ended when the control reached the maximum absorbance level.

Determining the reduction power according to FRAP method. The reduction power of iron ions $\left(\mathrm{Fe}^{3+}\right)$ was determined according to the Oyaizu method. Briefly, the measurement of the coloured complexes that are formed by the antioxidant compounds with $\mathrm{K}_{3} \mathrm{Fe}(\mathrm{CN})_{6}$, TCA and $\mathrm{FeCI}_{3}$ are performed. The increase in the absorbance level of the reaction mixture is directly proportional with the reducing power of the sample [22].

Determining DPPH free radical removal activity. For 2,2-diphenyl-1-picryl hydrazyl radical (DPPH) free radical removal activity, $1 \mathrm{mM}$ DPPH solution was used. The stock solutions were added to the test tubes at 25,50 and $100 \mu \mathrm{g} / \mu \mathrm{L}$ concentrations (respectively), and the total volume was completed to $3 \mathrm{~mL}$ with distilled ethanol. The absorbance scores at $517 \mathrm{~nm}$ against the blank (ethanol) were recorded. As a control, $3 \mathrm{~mL}$ ethanol and $1 \mathrm{~mL}$ DPPH solution were used [5].

Determining the reduction power according to the CUPRAC method

The cupric ion $\left(\mathrm{Cu}^{2+}\right)$ reduction capacities of the extracts were determined according to the CUPRAC method [2]. The absorbance of 25, 50, $100 \mu \mathrm{g} / \mathrm{mL}$ samples and standards at $450 \mathrm{~nm}$ were recorded. The increasing absorbance score of the reaction mixture shows the reduction capacity of cupric ion $\left(\mathrm{Cu}^{2+}\right)$.

Effect of the extracts on DNA

The effect of the extracts on the DNA was determined by using pBR322 plasmid DNA with the agarose gel electrophoresis method [29]. For this purpose, $200 \mathrm{mg}$ extract was dissolved in $1 \mathrm{~mL}$ dimethyl sulfoxide (DMSO) and stock extracts were prepared. 
By diluting these stock extracts, they were used in concentrations of 25, 50 and $100 \mathrm{mg} / \mathrm{mL}$. The samples that were prepared in PCR tubes were incubated at $37^{\circ} \mathrm{C}$ for 24 hours in dark [1]. After the incubation, $10 \mu \mathrm{L}$ extract DNA mixture was mixed with loading buffer and was then loaded to $1 \%$ agarose gel, and electro-phoresis was made in $40 \mathrm{~V}$, in free flow in TBE (Tris/Borate/EDTA) buffer for 2 hours. After the electrophoresis, the gels were stained with ethidium bromide, and were viewed as gel photos in CemiDoc XRS BIORAD imaging system.

Statistical analysis

The phenolic amount and the antimicrobial activity analysis results were performed in triplicate. The results were calculated as mean \pm standard deviation. Statistical significance was evaluated with the Tukey Test by using the GraphPad Prism 8 program. The differences were considered significant at $p<0.05$.

\section{Results and Discussion}

To determine the phenolic contents of $V$. insulare extracts, the analysis of the amounts was performed by HPLC using 17 different phenolic standards. The results are given in Table I. In the $V$. insulare LEtOH extract, vanillin $(246.30 \pm 2.15 \mu \mathrm{g} / \mathrm{mL})$ was determined at the maximum amount, and trans-p-coumaric acid $(2.65 \pm 1.06 \mu \mathrm{g} / \mathrm{mL})$ was determined at the minimum amount. In the LPW extract, on the other hand, quercetin $(0.48 \pm 0.01 \mu \mathrm{g} / \mathrm{mL})$ was determined at the minimum amount, and cinnamic acid $(105.60 \pm 1.43$ $\mu \mathrm{g} / \mathrm{mL}$ ) was determined at the maximum amount. In the REtOH extract, catechol $(121.00 \pm 0.99 \mu \mathrm{g} / \mathrm{mL})$ was determined at the maximum amount, and quercetin $(0.73 \pm 0.02 \mu \mathrm{g} / \mathrm{mL})$ was determined at the lowest amount. In the RPW extract; however, quercetin $(0.70 \pm 0.01 \mu \mathrm{g} / \mathrm{mL})$ was determined at the minimum level $(0.70 \pm 0.01 \mu \mathrm{g} / \mathrm{mL})$, and salicylic acid $(91.34 \pm$ $0.99 \mu \mathrm{g} / \mathrm{mL}$ ) was determined at the maximum amount. It was observed that the phenolic substance amounts were very different from each other in the plant extracts.

Table I

Phenolic substance amount in $V$. insulare extracts $(\mu \mathrm{g} / \mathrm{mL})$

\begin{tabular}{|c|c|c|c|c|}
\hline Phenolics & LEtOH & LPW & REtOH & RPW \\
\hline Ascorbic acid & $4.80 \pm 0.24$ & $6.67 \pm 0.66$ & $46.17 \pm 1.82$ & $88.78 \pm 1.14$ \\
\hline Gallic acid & $\mathbf{0 . 0 0} \pm \mathbf{0 . 0 0}$ & $\mathbf{0 . 0 0} \pm \mathbf{0 . 0 0}$ & $\mathbf{0 . 0 0} \pm \mathbf{0 . 0 0}$ & $0.00 \pm \mathbf{0 . 0 0}$ \\
\hline 3,4-dihydroxybenzoic acid & $0.00 \pm 0.00$ & $0.00 \pm 0.00$ & $0.00 \pm 0.00$ & $0.00 \pm 0.00$ \\
\hline 4-Hydroxybenzoic acid & $6.09 \pm 0.37$ & $1.33 \pm 0.17$ & $1.19 \pm 0.03$ & $1.05 \pm 0.06$ \\
\hline trans-p-coumaric acid & $2.65 \pm 1.06$ & $1.33 \pm 0.01$ & $12.40 \pm 0.13$ & $5.13 \pm 0.17$ \\
\hline Myricetin & $67.90 \pm 3.55$ & $35.70 \pm 3.56$ & $108.50 \pm 6.90$ & $22.02 \pm 1.50$ \\
\hline Abscisic acid & $13.09 \pm 0.57$ & $3.95 \pm 0.77$ & $9.42 \pm 0.13$ & $3.95 \pm 0.51$ \\
\hline Quercetin & $2.79 \pm 0.26$ & $0.48 \pm 0.01$ & $0.73 \pm 0.02$ & $0.70 \pm 0.01$ \\
\hline Apigenin & $66.68 \pm 4.05$ & $4.59 \pm 0.38$ & $21.56 \pm 3.09$ & $10.64 \pm 1.03$ \\
\hline Kaempferol & $6.82 \pm 0.37$ & $1.41 \pm 0.01$ & $5.58 \pm 0.58$ & $6.59 \pm 0.19$ \\
\hline Curcumin & $7.79 \pm 0.12$ & $0.00 \pm 0.00$ & $14.27 \pm 0.42$ & $4.89 \pm 0.49$ \\
\hline Catechol & $154.40 \pm 5.49$ & $15.96 \pm 1.92$ & $121.00 \pm 0.99$ & $54.12 \pm 1.78$ \\
\hline Vanillin & $246.30 \pm 2.15$ & $0.00 \pm 0.00$ & $0.00 \pm 0.00$ & $2.33 \pm 0.06$ \\
\hline Caffeic acid & $82.55 \pm 3.00$ & $5.80 \pm 0.06$ & $52.19 \pm 0.21$ & $21.86 \pm 0.75$ \\
\hline Cinnamic acid & $29.59 \pm 0.60$ & $105.60 \pm 1.43$ & $30.80 \pm 0.61$ & $12.03 \pm 0.09$ \\
\hline Rosmarinic acid & $58.38 \pm 2.69$ & $0.78 \pm 0.01$ & $10.36 \pm 0.11$ & $4.33 \pm 0.15$ \\
\hline Salicylic acid & $12.55 \pm 0.83$ & $0.00 \pm 0.00$ & $58.26 \pm 0.73$ & $91.34 \pm 0.99$ \\
\hline Total quantity & $726.30 \pm 11.82$ & $181.60 \pm 9.37$ & $479.10 \pm 14.28$ & $329.80 \pm 3.52$ \\
\hline
\end{tabular}

It was reported in previous studies that Verbascum species contained apigenin, apigenin glucoside, luteolin and luteolin glucoside phenolics [8, 9, 23]. In addition, in Verbascum species, the caffeic acid, rosmarinic acid, quercetin, apigenin, p-coumaric and protocatechuic acid (3,4-dihydroxybenzoic acid) presence were detected with by HPLC $[16,27]$. Since there are limited HPLC analysis results in the literature related to the plant samples used in this study, the presence of similar phenolics was observed when the Verbascum genus was considered. The acetone extract of $V$. pinetorum was reported to have luteolin, kaempferol and apigenin at the highest amount, and did not contain gallic acid [6]. The presence of gallic acid was not observed in any of our extracts. In the study conducted on Verbascum species, the phenolic amounts in the aqueous extracts were reported to be at the lowest concentrations [20]. The active principles from the used plant had higher solubility in ethanol; therefore, the ethanolic extract contains a large quantity of phenolics, compared due to the aqueous extract.

\section{Antimicrobial activity}

To clarify the antimicrobial activity features of $V$. insulare extracts on microorganisms, their antimicrobial activities against $B$. subtilis, $S$. aureus, B. megaterium, $E$. aerogenes, E. coli, $P$. aeruginosa, K. pneumoniae, $Y$. lipolytica, $C$. albicans and $S$. cerevisiae test microorganisms and antibiotics were determined as $\mathrm{mm}$ (Table II). 
FARMACIA, 2019, Vol. 67, 4

It was determined that the LEtOH extract showed the highest antifungal activity against $Y$. lipolytica and $C$. albicans and REtOH against $Y$. lipolytica. The extracts showed the lowest antifungal activity against $S$. cerevisiae. It was determined that the extracts did not show any antibacterial activity against the bacteria used in the study. For this purpose, only the antifungal activity results were compared with the fluconazole antibiotic results. It was determined that ethanolic extracts showed antifungal activity that was similar to that of fluconazole; however, aqueous extracts showed less activity.

In the previous studies that were conducted regarding the antimicrobial activity, it was determined that the extracts obtained from Verbascum plants showed antimicrobial activity against $E$. coli [27], S. aureus [32], C. albicans [6], S. epidermidis and Salmonella enteritidis [18]. In this study, it was determined that the extracts did not show any antibacterial activity and they only presented antifungal activity. In a previous study, when the antimicrobial activity test results of $V$. sinaiticum extracts were examined, it was determined that they showed similar activity as gentamycin, which was used as a positive control against $P$. aeruginosa and $S$. aureus [30]. In this study, it was determined that ethanol extracts showed antifungal activity that was similar to fluconazole against $Y$. lipolytica and C. albicans.

Table II

The antimicrobial effect of $V$. insulare extracts and antibiotic against test microorganisms (mm)

\begin{tabular}{|c|c|c|c|c|}
\hline \multirow{2}{*}{\multicolumn{2}{|c|}{ Extracts (DMSO $10 \mathrm{mg} / \mathrm{mL})$ and antibiotic }} & \multicolumn{2}{|c|}{ Yeast } & \multirow[b]{2}{*}{ S. cerevisiae } \\
\hline & & Y. lipolytica & C. albicans & \\
\hline \multirow[t]{5}{*}{ (a) } & $5 \mu \mathrm{l}$ & $0.00 \pm 0.00$ & $13.67 \pm 0.58$ & $0.00 \pm 0.00$ \\
\hline & $10 \mu \mathrm{l}$ & $0.00 \pm 0.00$ & $16.33 \pm 0.58$ & $0.00 \pm 0.00$ \\
\hline & $20 \mu 1$ & $13.33 \pm 1.52$ & $19.00 \pm 0.00$ & $0.00 \pm 0.00$ \\
\hline & $40 \mu \mathrm{l}$ & $18.00 \pm 1.00$ & $21.00 \pm 1.00$ & $0.00 \pm 0.00$ \\
\hline & $80 \mu \mathrm{l}$ & $23.67 \pm 1.52$ & $24.67 \pm 0.58$ & $0.00 \pm 0.00$ \\
\hline \multirow{5}{*}{ LPW } & $5 \mu 1$ & $0.00 \pm 0.00$ & $0.00 \pm 0.00$ & $0.00 \pm 0.00$ \\
\hline & $10 \mu \mathrm{l}$ & $0.00 \pm 0.00$ & $0.00 \pm 0.00$ & $0.00 \pm 0.00$ \\
\hline & $20 \mu \mathrm{l}$ & $0.00 \pm 0.00$ & $0.00 \pm 0.00$ & $0.00 \pm 0.00$ \\
\hline & $40 \mu \mathrm{l}$ & $15.00 \pm 1.00$ & $11.33 \pm 0.58$ & $14.00 \pm 1.00$ \\
\hline & $80 \mu \mathrm{l}$ & $17.67 \pm 0.58$ & $16.00 \pm 0.00$ & $17.67 \pm 0.58$ \\
\hline \multirow{5}{*}{ REtOH } & $5 \mu 1$ & $12.33 \pm 0.58$ & $12.00 \pm 0.00$ & $0.00 \pm 0.00$ \\
\hline & $10 \mu \mathrm{l}$ & $15.33 \pm 0.58$ & $16.33 \pm 0.58$ & $0.00 \pm 0.00$ \\
\hline & $20 \mu 1$ & $17.00 \pm 0.00$ & $17.00 \pm 0.00$ & $0.00 \pm 0.00$ \\
\hline & $40 \mu 1$ & $18.67 \pm 0.58$ & $18.00 \pm 0.00$ & $11.00 \pm 0.00$ \\
\hline & $80 \mu \mathrm{l}$ & $23.67 \pm 1.53$ & $18.33 \pm 0.58$ & $11.67 \pm 0.58$ \\
\hline \multirow{6}{*}{ RPW } & $5 \mu 1$ & $0.00 \pm 0.00$ & $0.00 \pm 0.00$ & $0.00 \pm 0.00$ \\
\hline & $10 \mu \mathrm{l}$ & $0.00 \pm 0.00$ & $0.00 \pm 0.00$ & $0.00 \pm 0.00$ \\
\hline & $20 \mu 1$ & $0.00 \pm 0.00$ & $15.33 \pm 0.58$ & $0.00 \pm 0.00$ \\
\hline & $40 \mu 1$ & $15.67 \pm 0.58$ & $17.00 \pm 0.00$ & $0.00 \pm 0.00$ \\
\hline & $80 \mu \mathrm{l}$ & $19.67 \pm 1.53$ & $18.67 \pm 0.58$ & $14.00 \pm 0.00$ \\
\hline & $25 \mu \mathrm{g}$ & $20.67 \pm 0.58$ & $22.67 \pm 0.58$ & $0.00 \pm 0.00$ \\
\hline
\end{tabular}

\section{Antioxidant activity}

The in vitro antioxidant features of the extracts and standards were examined by using different methods, and the results are shown in Figure 1. For the purpose of measuring the total antioxidant activity values of $V$. insulare extracts, the absorbances of the extracts and standards were measured every 10 hours. The concentrations of 25,50 and $100 \mu \mathrm{g} / \mathrm{mL}$ were used for the total antioxidant activity of the samples and standard antioxidants (butylated hydroxyanisole (BHA) and butylated hydroxytoluene (BHT)). When the control reached maximum absorbance after the $40^{\text {th }}$ hour, the experiment was declared finished and the percentages of the extracts and standards at $100 \mu \mathrm{L}$ concentration for destruction of lipid peroxidation were measured in the following order: LEtOH: $66.68 \%>$ BHA: $64.02 \%>$ BHT: $61.37 \%>$ LPW: $47.74 \%>$ RPW: $21.10 \%>$ REtOH: $15.06 \%$.
When the results of the reduction power were considered according to FRAP and CUPRAC methods, the activities of the extracts and standards generally increased depending on concentration. The strength of the extracts and standards at $100 \mu \mathrm{L}$ concentration for iron ions was measured in the following order: $\mathrm{BHA}>\mathrm{LEtOH}>\mathrm{BHT}>\mathrm{REtOH}>\mathrm{LPW}>\mathrm{RPW}$. In addition, the reduction power of copper ions at the same concentration was determined in the following order: $\mathrm{REtOH}>\mathrm{LEtOH}>\mathrm{BHT}>\mathrm{BHA}>\mathrm{LPW}>\mathrm{RPW}$. When the scavenging activities of the extracts and standards at $100 \mu \mathrm{L}$ concentration for DPPH radicals were examined, it was determined that the leaf and root ethanolic extracts showed higher activity than BHA and BHT; and aqueous extracts did not show significant activity. The radical removal percentages of the extracts and standards were determined to be REtOH: $24.04 \% \geq$ LEtOH: $23.12 \%$ > BHA: $13.64 \%$ > BHT: 8.26\%). 
In previous studies conducted on different species of Verbascum genus, it was reported in general that the aqueous extract presented a lower lipid peroxidation activity compared to other solvents $[10,20]$, lower DPPH radical removal activity [2, 6, 23], and lower reduction capacity in iron and copper ions $[10,20]$. Unlike these studies, in a study that was conducted on Verbascum glabratum subsp. bosnense (K. Maly), it was reported that the aqueous extract had exhibited
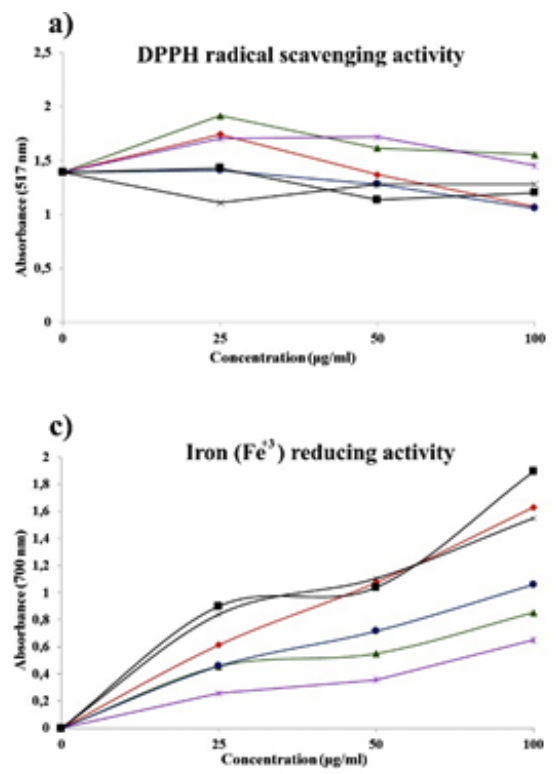

higher antioxidant activity than that of the ethanolic extract [15].

Although this study supports the results of the abovementioned studies in general, it also differed from previous studies because different solvents were used. In addition, when the phenolic contents were considered, the total phenolic contents of ethanol extracts were higher than that of the aqueous extracts. It may be argued that the antioxidant activity of the ethanolic extract is stronger because of this reason.

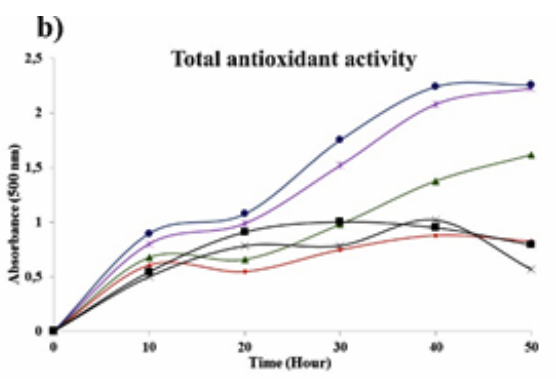

d)

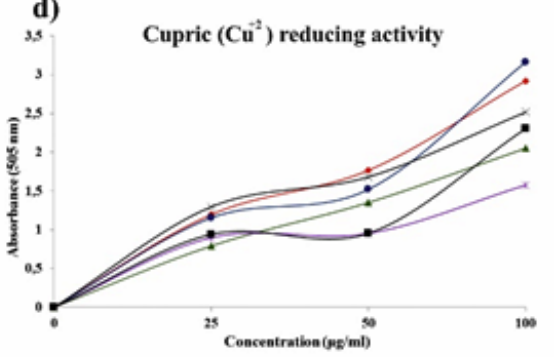

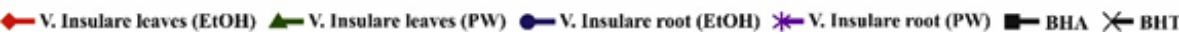

Figure 1.

a) DPPH scavenging activities of plant extracts and standards (BHA and BHT); b) the results of total antioxidant activities of extracts and standards by thiocyanate method; c) the $\mathrm{Fe}^{3+}$ reducing power of samples by FRAP;

d) the $\mathrm{Cu}^{2+}$ reducing the power of samples by CUPRAC

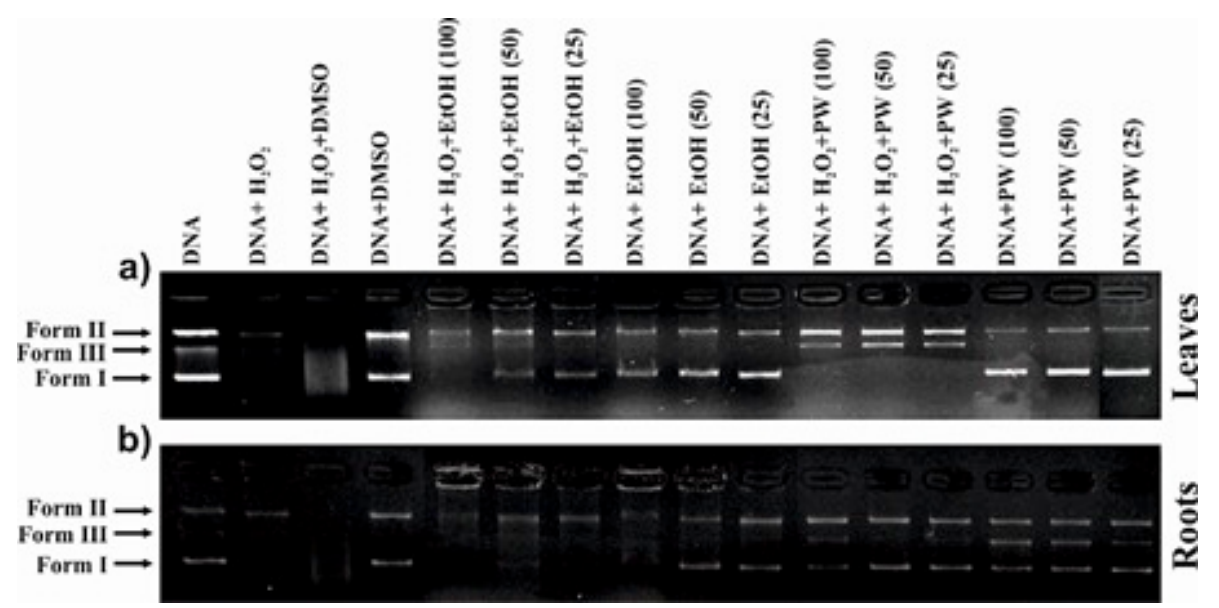

Figure 2.

a) Electrophoresis imaging of DNA protective activities of EtOH and PW extracts obtained from $V$. insulare's leaves; b) Electrophoresis imaging of DNA protective activities of EtOH and PW extracts $(\mathrm{mg} / \mathrm{mL})$ obtained from $V$. insulare's roots

DNA protective activity

DNA can be found in different forms in living organisms, and these forms are shaped according to the genetic characteristics of the organism. When any molecule interacts with the DNA, these forms may be disrupted or converted into each other. The dual- 
chain super-helical structure of the DNA is known as Form I. Form II occurs in the agarose gel following the breakage of one of the strands that constitute Form I structure. In addition, after the breakage of the other chain, the DNA becomes linear, and this structure is known as Form III [37]. The changes that take place in the interactions between the extracts used in this study and the plasmid DNA were determined by observing the Form I, Form II and Form III conversions (Figure 2).

It was observed that the ethanolic extracts stabilized the DNA by eliminating the scavenging effect of $\mathrm{H}_{2} \mathrm{O}_{2}+$ DMSO depending on the concentration. It was also determined that pure aqueous extracts eliminated partially the scavenging effect on the DNA. Meanwhile, it was also determined that the extracts ensured that the DNA remained more stable when applied alone. When the concentrations and incubation times of the extracts were considered, no remarkable results were observed.

It was reported that the methanolic extracts of Russelia equisetiformis, which belonged to the Scrophulariaceae family [36] and Mazus goodenifolius [24] made the DNA stabilized by removing the scavenging effect of $\mathrm{H}_{2} \mathrm{O}_{2}$. It was also reported that the methanolic extract of $V$. pinetorum did not have any significant effects on the DNA division protection [6]. In this study, it was observed that especially the ethanolic extract; partly the pure aqueous extract eliminated the scavenging effect of $\mathrm{H}_{2} \mathrm{O}_{2}+$ DMSO and stabilized the DNA by providing protective activity on pBR322 plasmid DNA.

\section{Conclusions}

In the literature review, it was observed that the studies conducted on phenolic content and biological activity of $V$. insulare were very limited. For this reason, in the present study, the phenolic substance amount of the $V$. insulare extracts were examined with HPLC; and their in vitro biological activities were investigated. Gallic acid and 3,4-dihydroxy-benzoic acid presence were not detected in all extracts, which was a common finding. It was determined that ethanolic extracts showed similar activity only to fluconazole, and had better antifungal activity compared to pure aqueous extracts. When the antioxidant study results were examined, it was observed that ethanolic extract had better activity than pure aqueous extract. Meanwhile, it was also observed that ethanolic extracts and partly pure aqueous extracts eliminated the scavenging effects of $\mathrm{H}_{2} \mathrm{O}_{2}+$ DMSO and ensured protective activity on pBR322 plasmid DNA, and in this way, stabilized the DNA. It is considered that the antifungal, antioxidant and DNA protective activity of ethanolic extracts occur due to the fact that they contain a higher amount of phenolic substances. In general terms, it is considered that the obtained data from some $V$. insulare species rather than Verbascum genus in the literature will contribute significantly to studies performed on foods, pharmaceutical applications and literature.

\section{Acknowledgement}

I thank Dr. Ahmet Savc1 and Dr. Murat Kurşat for their precious contributions to the present study.

\section{References}

1. Alan Y, Evaluation of phenolic substance content and biological activities of Arum elongatum steven extracts. BEU J Sci., 2018; 7: 370-379.

2. Aprotosoaie AC, Ciocârlan N, Brebu M, Trifan A, Grădinaru AC, Miron A, Chemical composition, antioxidant and antimicrobial activities of Mentha gattefossei maire essential oil. Farmacia, 2018; 66, 778-782.

3. Baytop T, Treatment with Plants in Turkey (Türkiye'de Bitkilerle Tedavi). İstanbul Üniversitesi Yayınları, Istanbul, 1984; 40, (available in Turkish).

4. Baytop T, Treatment with Plants in Turkey (Past and Today) (Türkiye'de Bitkilerle Tedavi (Geçmişte ve Bugün)). Nobel Tıp Kitabevleri Ltd., Istanbul, 1999; 334-335, (available in Turkish).

5. Blois MS, Antioxidant determinations by the use of a stable free radical. Nature, 1958; 181: 1199.

6. Boğa M, Ertaş A, Yılmaz MA, Kızıl M, Çeken B, Haşimi N, Özden TY, Demirci S, Yener İ, Deveci Ö, UHPLC-ESI-MS/MS and GC-MS analyses on phenolic, fatty acid and essential oil of Verbascum pinetorum with antioxidant, anticholinesterase, anti-microbial and DNA damage protection effects. Ir J Pharm Res., 2016; 15: 393-405.

7. Brull S, Coote P, Preservative agents in foods: mode of action and microbial resistance mechanisms. Int J Food Microbiol., 1999; 50: 1-17.

8. Dalar A, Bengu AS, Allahverdiyev O, Analysis of phytochemical composition and biological activities of Verbascum cheiranthifolium var. cheirenathifolium stem and flowers. Int J Second Metab., 2018; 5: 233-242.

9. Dalar AY, Guo Y, Konczak I, Phenolic composition and potential anti-inflammatory properties of Verbascum cheiranthifolium var. cheiranthifolium leaf. J Herb Med., 2014; 4: 195-200.

10. Danahaliloğlu H, Determination of Some Chemical and Biological Properties of Various Verbascum Species Growing in Hatay (Hatay Bölgesinde Yetişen Çeşitli Verbascum Türlerinin Bazı Kimyasal ve Biyolojik Özelliklerinin Belirlenmesi). Mustafa Kemal University, Hatay, 2014; 52-63, (available in Turkish).

11. Davis PH, Flora of Turkey and the East Aegean Islands. Edinburgh University, 1970; 3.

12. Dulger B, Gonuz A, Antimicrobial activity of some endemic Verbascum, Salvia, and Stachys species. Pharm Biol., 2004; 42: 301-304.

13. Güner A, Özhatay N, Tuna E, Scrophulariaceae Flora of Turkey and the East Aegean Islands. (Supplement 2) Edinburgh: Edinburgh University Press, 2000; 11: 193. 
14. Huber AM, Verbascum L.; in Davis P.H., ed., Flora of Turkey and the East Aegean Islands 6, Edinburg University Press, Edinburgh, 1978; 461-603.

15. Karalija E, Parić A, Dahija S, Gajević RB, Zeljković $\mathrm{SC}$, Phenolic compounds and bioactive properties of Verbascum glabratum subsp. bosnense (K. Malý) Murb., an endemic plant species. Nat Prod Res., 2018.

16. Klimek B, Olszewska MA, Tokar M, Simultaneous determination of flavonoids and phenylethanoids in the flowers of Verbascum densiflorum and $V$. phlomoides by high-performance liquid chromatography. Phytochem Anal., 2010; 21: 150-156.

17. Küpeli E, Tatlı I, Akdemir ZS, Yeşilada E, Bioassayguided isolation of anti-inflammatory and antinociceptive glycoterpenoids from the flowers of Verbascum lasianthum Boiss. ex Bentham. $J$ Ethnopharmacol., 2007; 110: 444-450.

18. Magiatis P, Spanakis D, Mitaku S, Tsitsa E, Mentis A, Harvala C, Verbalactone, a new macrocyclic dimer lactone from the roots of Verbascum undulatum with antibacterial activity. J Nat Prod., 2001; 64: 1093-1094.

19. Mantle D, Anderton JG, Falkous G, Barnes M, Jones P, Perry EK, Comparison of methods for determination of total antioxidant status: Application to analysis of medicinal plant essential oils. Compar Biochem Physiol Part B: Biochem Mol Biol Int., 1998; 121: 385-391.

20. Mihailovi'c V, Kreft S, Benkovi'c ET, Ivanovi'c N, Stankovi'c MS, Chemical profile, antioxidant activity and stability in stimulated gastrointestinal tract model system of three Verbascum species. Ind Crops Prod., 2016; 89: 141-151.

21. Mitsuda $\mathrm{H}$, Antioxidative action of indole compounds during the autoxidation of linoleic acid. Eiyo to Syokuryo, 1966; 19: 210-214.

22. Oyaizu M, Studies on product of browning reaction prepared from glucosamine. Jpn J Nutr., 1986; 44: 307-315.

23. Pauna G, Neagua E, Albua C, Radu GL, Verbascum phlomoides and Solidago virgaureae herbs as natural source for preventing neurodegenerative diseases. $J$ Herb Med., 2016; 6: 180-186.

24. Riaz M, Rasool N, Bukhari IH, Shahid M, Zubair M, Rizwan K, Rashid U, In vitro antimicrobial, antioxidant, cytotoxicity and GC-MS analysis of Mazus goodenifolius. Molecules, 2012; 17: 14275-14287.

25. Robbers JE, Tyler VE, Tyler's Herbs of Choice (The Therapeutic Use of Phytomedicinals). The Harworth Herbal Press, New York, 1999; 119.

26. Sagdic O, Karahan A, Ozcan M, Ozkan G, Note: Effect of some spice extracts on bacterial inhibition. Food Sci Technol Int., 2003; 9: 353-358.

27. Saltan FZ, Sökmen M, Akın M, Saraçaoğlu HT, Göktürk RS, Ahmad M, Ali M, Shah MR,
Antimicrobial and antioxidant activities of phenolic compound extracted from new Verbascum species growing in Turkey. J Chem Soc Pak., 2011; 33: 764-771.

28. Sibanba T, Okoh AI, The challenges of overcoming antibiotic resistance plant extracts as potential sources of antimicrobial and resistance modifying agents. Africa Biotech., 2007; 6: 2886-2896.

29. Siddall TL, Ouse DG, Benko ZL, Garvin GM, Jackson JL, McQuiston JM, Ricks MJ, Thibault TD, Turner JA, Vanheertum JC, Weimer MR, Synthesis and herbicidal activity of phenyl-substituted benzoylpyrazoles. Pest Manag Sci., 2002; 58: 1175-1186.

30. Taged H, Mohammed E, Asres K, Mariam TG, Antimicrobial activities of some selected traditional Ethiopian medicinal plants used in the treatment of skin disorders. J Ethnopharmacol., 2005; 100: 168-175.

31. Tapan S, Quantitative HPLC analysis of phenolic acids, flavonoids and ascorbic acid in four different solvent extracts of two wild edible leaves, Sonchus Arvensis and Oenanthe Linearis of north-eastern region in India. J Appl Pharm Sci., 2016; 6: 157-166.

32. Turker AU, Camper N, Biological activity of common mullein, a medicinal plant. J Ethnopharmacol., 2002; 82: $117-125$

33. Utsukarcı BS, Dosler S, Taskın T, Abudayyak M, Ozhan G, Mat A, An Evaluation of antioxidant, antimicrobial, antibiofilm and cytotoxic activities of five Verbascum species in Turkey. Farmacia, 2018; 66: 1014-1020.

34. Vichi S, Zitterl Eglseer K, Jugl M, Franz C, Determination of the presence of antioxidants deriving from sage and oregano extracts added to animal fat by means of assessment of the radical scavenging capacity by photo-chemiluminescence analysis. Food/Nahrung, 2001; 45: 101-104.

35. Yalçın SM, Flavonoids from Verbascum cheiranthifolium boiss. Marmara Pharmaceut J., 1989; 8: 93-97.

36. Yoshikawa Y, Hizume K, Oda Y, Takeyasu K, Araki $\mathrm{S}$, Yoshikawa K, Protective effect of vitamin $\mathrm{C}$ against double-strand breaks in reconstituted chromatin visualized by single-molecule observation. Biophys J., 2006; 90: 993-999.

37. Zhang H, Barcelo JM, Lee B, Kohlhagen G, Zimonjic DB, Popescu NC, Pommier Y, Human mitochondrial topoisomerase. Proc Natl Acad Sci USA., 2001; 98: 10608-10613.

38. Rashid MA, Akhtar MN, Ashraf A, Nazir S, Ijaz A, Omar NA, Noor S, Basit A, Tareen RB, Chemical composition and antioxidant, antimicrobial and haemolytic activities of Crambe cordifolia roots. Farmacia, 2018; 66, 165-171. 